\title{
Linacre Derived Potential Evapotranspiration Method and Effect on Supplementary Irrigation Water Needs of Tomato/Cabbage/Carrot
}

\author{
Emeribe C.N. ${ }^{1}$, Isagba E.S. ${ }^{2}, *$ and Idehen O.F. ${ }^{3}$ \\ ${ }^{1}$ National Centre for Energy and Environment, University of Benin, Benin City, Nigeria \\ ${ }^{2}$ Department of Civil Engineering, University of Benin, Benin City, Nigeria \\ ${ }^{3}$ Department of Geography and Regional Planning, Igbinedion University, Okada, Nigeria \\ Corresponding Author: *ebuwa.isagba@uniben.edu
}

\begin{abstract}
The study examined the dynamic nature of water balance parameters over Kano town, a semi-arid environment and impact of Linacre derived potential evapotranspiration method on the supplementary irrigation water needs of selected crops. Monthly Rainfall and Temperature data were collected from the Nigerian Meteorological Agency, Lagos for the period 1953-2012. The study observed that there is a steady decline in annual precipitation over Kano from the first decade (1953-1962) to the fifth decade (1993-2002), after which there was a sign of weak recovery in the last decade (2003-2012). For water loss through potential evapotranspiration, there was a steady rise from the first decade (1953-1962) to the fifth decade (1993-2002), and then followed by a sudden decline in the last decade (2003-2012). The total average of water storage on the other hand, first experienced a rise between the first two decades (1953-1962) and (1963-1972), followed by a steady decline, up until the fifth decade (1993-2002) and finally a rise in the last decade (20032012). The total average of soil water deficit experienced a steady rise between the first and the fifth decades (1953-1962) to (1993-2002), this was followed by a decline in the last decade (20032012). Finally, the total average of water surplus experienced a steady decline between the first and the fifth decades. The observed decline in precipitation, storage, and water surplus, and the rise in water loss from potential evapotranspiration and soil water deficit, suggests that there have been changes in the climatic pattern over Kano and this could be seen in the supplementary irrigation water needs of Tomato/Cabbage/Carrot.
\end{abstract}

Keywords: Water Balance, Climate Change, Decadal Pattern, Water Resources Management

\subsection{Introduction}

From a hydrologic viewpoint, precipitation constitutes almost the entire water supply to any region but more importantly in the tropics. However, its water potential can never be assessed from precipitation alone. It is necessary to know whether the precipitation is greater or less than the water need as determined essentially by the maximum amount of evaporation and transpiration, or the evapotranspiration (Thornthwaite, 1948). Where the precipitation is high, the region is wet and where the precipitation is low in comparison with the water need, the region is dry. The mutual comparison of precipitation and potential evapotranspiration for the evaluation of water balance, i.e. for quantitatively assessing the adequacy of precipitation (as water supply) in relation to potential evapotranspiration (as water need) may be effectively performed employing a simple accounting procedure devised by (Thorntrawaite, 1948). In this procedure, based on the hydrological cycle, precipitation is treated as income, potential evapotranspiration as expenditure and the amount of moisture stored in the soil as a sort of reserve available for use to a limited extent for purposes of evapotranspiration during rainless periods. Where the precipitation is exactly the same as the potential evapotranspiration all of the time and water is available for use just as needed, there is neither water deficiency nor excess; the climate of the station is neither wet nor dry. As water deficiency (precipitation less than potential evapotranspiration) becomes large with respect to water need, the 
climate becomes progressively drier or more arid and as the water surplus (precipitation greater than potential evapotranspiration) becomes larger, the climate becomes progressively wetter or more humid.

According to Dettinger and Diaz (2000); Sauchyn and Kulshreshtha (2008) climate change has brought about alterations in various processes and activities that influence the provision of water resources in basins. This calls for proper evaluation of water availability in regions of the world. Equally, the various components of climatic water balance have also been affected hence evaluation of the water budget of a basin, potentially identifies the genesis of climate change in a region of interest. Climate change affects various aspects of the water resources of a basin, it may give rise to either too much, or too little water. In situations where rainfall over a region is affected, the resultant effect manifests in various aspects of human activities, agricultural activity being one of them.

The Northern part of Nigeria where Kano State is located, experiences less rainfall amounts than southern Nigeria (Tarhule and Woo, 1998; Ekpoh, 1999; Hulme, 2001; Dai et al., 2004; Adefolalu 2007; Ekpoh , 2007) resulting in agricultural practices not being dependent on rain-fed agriculture but rather on irrigation. The need to understand the water availability pattern of the region through water balance is thus imperative. In addition, monitoring and controlling water balance in a region is valuable to the efficient management of the water and soil of the region. The knowledge of water balance is useful in deciding the possible methods to minimize loss and to maximize gain and in the utilization of water which is often a limiting factor in crop production. In this study therefore, the climatic water balance of Kano State was examined using the Thornthwaite (1948) model and the Linacre (1977) potential evapotranspiration calculation method, in order to investigate the amount of water resources available in the study area in the past decades (from 1953 - 2012); and to also examine the pattern of hydrological behaviour of the state over the period of six decades.

\subsection{Materials and Methods}

\subsection{Study area}

The study area is Kano town in Kano State of Nigeria. The town lies within Latitude $10^{\circ} 0{ }^{\prime} 48 \mathrm{~N}$ and $12^{\circ} 0^{\prime} 0.30^{\prime \prime} \mathrm{N}$ and Longitude $7^{\circ} 0^{\prime} 59^{\prime \prime} \mathrm{E}$ and $9^{\circ} 0^{\prime} 11 " \mathrm{E}$ (Figure 1). The area is bounded to the north by Niger republic, to the south by Bauchi State, to the east by Jigawa State, and to the west by Kaduna and Katsina states. The study area covers an area of approximately $42,592 \mathrm{~km}^{2}$ (Mamman et al., 2002).

\subsection{Data collection}

Monthly Rainfall in $\mathrm{mm}$ and Temperature in 0C were collected from the Nigerian Meteorological Agency, Lagos for the period 1953-2012. The rainfall and temperature data were divided into decades before computation; from 1953 - 1962, 1963 - 1972, 1973 - 1982, 1983 - 1992, 1993 - 2002, and $2003-2012$ to create the decadal pattern required for this study. Afterwards, the computation of the potential evapotranspiration was carried out, using the Linacre (1977) method of analysis. Computation of the potential evapotranspiration was executed for each decade employing the total average decadal climatic component values (which include; temperature, precipitation and dew point) for each month. Elevation and latitude remained constant throughout computation. The results for the potential evapotranspiration were therefore presented in decadal form, showing the values for each month. This was followed by climatic water balance computation in decades, using the Thornthwaite (1948) budget method of analysis.

\subsection{Data analysis}

To estimate the values of the potential evapotranspiration of our study area, the Linacre (1977) model was used. This is because the model is suitable for West African climates and is thus superior to the Thornthwaite model over West Africa and can be used as a substitute for the Penman method with confidence (Anyadike 1987). By simplifying the Penman's formula, Linacre (1977) proposed the formulae for estimating values of evaporation and potential evapotranspiration. This formula is given as: 
$P E T=\frac{\frac{500 T_{m}}{100-A}+15\left(T-T_{d}\right)}{80-T}$

where:

$T_{m} \quad$ Temperature +0.006 (Elevation)

A Latitude

$T \quad$ Temperature in ${ }^{\circ} \mathrm{C}$

$T_{d} \quad$ Dew point

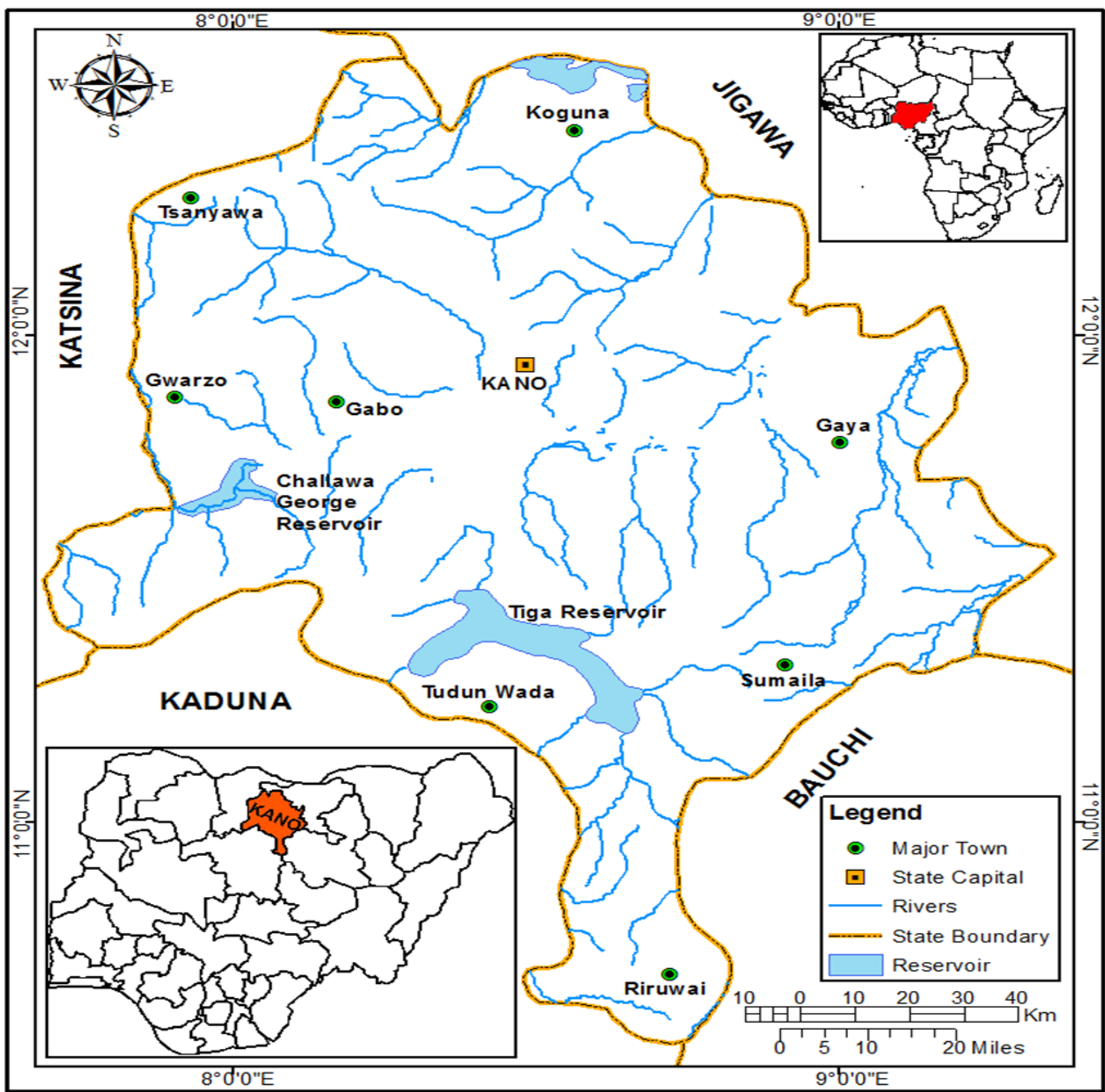

Figure 1: Map of Kano State, Nigeria

In the absence of data for dew point, estimation method developed by Linacre (1992) was used. The equation is given as:

$T_{d}=T_{\max }+0.8 C-14$

where:

$T_{\max } \quad$ Temperature in ${ }^{\circ} \mathrm{C}$

0.8 Constant

With the knowledge of the monthly precipitation, potential evapotranspiration values and soil moisture holding capacity of the study area, other water budget elements such as actual 
evapotranspiration, change in storage, soil moisture deficit and surplus were calculated as arithmetical differences either positive or negative, between precipitation and potential evapotranspiration values.

The moisture storage of any soil cannot be directly obtained unless the field capacity of the soil is known. According to Thornthwaite and Mather (1955) the field capacity of a soil is the optimum amount of water a given soil can contain. Information on soil moisture holding capacity is often scarce in developing countries. In the absence of data on soil moisture holding capacity, suitable values are frequently assumed based on vegetation and soil characteristics of the region. In this study field capacity value of 300 was used as have suggested by Anyadike (1992).

\subsection{Monthly supplementary irrigation water needs}

To ascertain if monthly supplementary irrigation for any of the selected crops (Tomato/Cabbage/Carrot) is required, the model designed by FAO (1986) for estimating supplementary irrigation need was used. The equation is given as:

$I R=E T_{\text {crop }}-P_{e}^{\text {month-1 }}$

where:

$I R \quad$ Supplementary irrigation in $\mathrm{mm}$

$E T_{\text {crop }} \quad$ Consumptive water need in $\mathrm{mm}$

$P_{e} \quad$ Effective rainfall in $\mathrm{mm}$

$E T_{\text {crop }}$ is defined as the depth (or amount) of water needed to meet the water loss through evapotranspiration. It is determined as:

$E T_{\text {crop }}=E T_{0} \times K_{c}$

where:

$E T_{0} \quad$ Reference crop evapotranspiration $\mathrm{mm}^{\mathrm{d}-1}$ as well as represents an index of climatic demand. $E T_{0}$ was determined using the Linacre model.

Because of the sparseness of data on crop coefficient $\left(K_{c}\right)$ in developing countries, empirical estimates are usually employed and the most common is the FAO estimates FAO, (1986). The $K_{c}$ values as estimated crop initial stage, development stage, mid-season stage and late season stage by FAO (1986) was used. In this study however, the development and mid-season stages have been bridged together as flowering stage, while initial and late season stage is considered as vegetative and harvesting stages respectively. This re-grouping/consideration is in line with three stages of crop growth according to Israelsen and Hansen (1962) classification i.e. vegetative, flowering and harvesting stages. According to the author, about $40-60 \%$ of water consumed by a crop is during the flowering stage while the remaining percentage is shared between the vegetative and harvesting stages.

\subsection{Results and Discussion}

\subsection{Results}

The result of the average monthly water balance components for each decade is given in Table 1. For the decade $(1953$ - 1962), total average precipitation was $(772.45 \mathrm{~mm})$, with the highest rainfall being recorded in the month of August. The total average of storage was $(1,506.69 \mathrm{~mm})$. The study area experienced a period of moisture deficit for up to eight months (January to May) and (October to December) with a total average of $(265.51 \mathrm{~mm})$. May to August was periods of soil moisture recharge. The period of soil moisture utilization was from August to October. Water surplus was recorded in August and September in this decade with a total average of (242.7 mm). However, large periods of soil moisture deficits were recorded especially at the beginning and end of the year, disrupting water availability during those periods. Hence, irrigation practices during those periods (January to May with May being the onset of rainfall and October to December with October being the rainfall departure month) would have been necessary, groundwater supply would also have been 
limited or unavailable, as well as the year-round availability and utility of water disrupted during those periods (Table 2).

Table 1: The Water Balance over Kano Town for the Years (1953 - 1962)

\begin{tabular}{|c|c|c|c|c|c|c|c|c|c|c|c|c|c|}
\hline & J & F & M & A & M & J & J & A & S & O & N & D & Total \\
\hline P & 0 & 0 & 0.89 & 14.03 & 38.21 & 71.76 & 173.01 & 278.09 & 175.13 & 21.33 & 0 & 0 & 772.45 \\
\hline PET & 34.58 & 37.10 & 45.94 & 51.84 & 52.23 & 44.25 & 40.4 & 38.01 & 32.63 & 42.96 & 40.73 & 34.59 & 495.26 \\
\hline ST & 0 & 0 & 0 & 0 & 0 & 27.51 & 160.12 & 300 & 300 & 278.37 & 237.64 & 203.05 & $1,506.69$ \\
\hline DST & 0 & 0 & 0 & 0 & 0 & +27.51 & +132.61 & +139.88 & 0 & -21.63 & -40.73 & -34.59 & \\
\hline AE & 0.3 & 0 & 0.89 & 14.03 & 38.31 & 44.25 & 40.4 & 38.01 & 32.63 & 21.33 & 0 & 0 & 229.85 \\
\hline DET & 34.58 & 37.10 & 45.05 & 37.81 & 14.02 & 0 & 0 & 0 & 0 & 21.63 & 40.73 & 34.59 & 265.51 \\
\hline
\end{tabular}

Table 2: Monthly supplementary irrigation water need for Tomato/Cabbage/Carrot in mm, over Kano State $(1953-1962)$

\begin{tabular}{|c|c|c|c|c|c|c|c|c|c|c|c|c|}
\hline & Jan & $\mathrm{Feb}$ & Mar & Apr & May & Jun & Jul & Aug & Sep & Oct & Nov & Dec \\
\hline & & & & & \multicolumn{2}{|c|}{$\begin{array}{l}\text { Crop initial } \\
\text { growth stage }\end{array}$} & \multicolumn{2}{|c|}{$\begin{array}{c}\text { Crop development } \\
\text { stage }\end{array}$} & \multicolumn{2}{|c|}{$\begin{array}{l}\text { Late season } \\
\text { stage }\end{array}$} & & \\
\hline $\mathrm{ET}_{0}(\mathrm{~mm})$ & 34.58 & 37.10 & 45.94 & 51.84 & 52.23 & \begin{tabular}{|l}
44.25 \\
\end{tabular} & 40.4 & 38.01 & 32.63 & 42.96 & 40.73 & 34.59 \\
\hline $\mathrm{K}_{\mathrm{c}}$ & & & & & 0.45 & 0.45 & 0.9 & 0.9 & 0.70 & 0.7 & & \\
\hline $\mathrm{ET}_{\text {crop }}$ & & & & & 23.5 & 19.9 & 36.4 & 34.2 & 22.8 & 30.1 & & \\
\hline $\mathrm{P}_{\mathrm{e}}(\mathrm{mm})$ & 0 & 0 & 0 & 0 & 12.75 & 34.2 & 112.6 & 176 & 112.5 & 2 & 0 & 0 \\
\hline IR (mm) & & & & & 10.75 & -14.3 & -76.2 & -141.8 & -89.7 & 28.1 & & \\
\hline
\end{tabular}

For the decade (1963 - 1972), total average precipitation was (770.28) with the highest rainfall month as August (Table 3). The total average of storage was $(1,611.52 \mathrm{~mm})$. The study area experienced a period of soil moisture deficit of up to eight months (January to May) and (October to December), with a total average of $(268.02 \mathrm{~mm})$. May to August was periods of soil moisture recharge, and the period of soil moisture utilization was from August to October. Water surplus was recorded in August and September with a total average of $(239.83 \mathrm{~mm})$. In the onset of rain when farmers would begin cultivation, supplementary irrigation was needed (Table 4).

Table 3: The Water Balance over Kano town for the Years $(1963-1972)$

\begin{tabular}{|c|c|c|c|c|c|c|c|c|c|c|c|c|c|}
\hline Decades & $\mathrm{J}$ & $\mathrm{F}$ & $\mathrm{M}$ & $\mathrm{A}$ & $\mathrm{M}$ & $\mathrm{J}$ & $\mathrm{J}$ & $\mathrm{A}$ & $\mathrm{S}$ & $\mathrm{O}$ & $\mathrm{N}$ & $\mathrm{D}$ & Total \\
\hline P & 0.3 & 0 & 0.28 & 12.57 & 38.03 & 101.16 & 205.83 & 262.75 & 128.73 & 20.58 & 0.05 & 0 & 770.28 \\
\hline PET & 33.59 & 38.13 & 53.16 & 52.16 & 50.6 & 45.03 & 39.38 & 37.18 & 39.05 & 38.91 & 38.99 & 34.32 & 500.5 \\
\hline ST & 0 & 0 & 0 & 0 & 0 & 56.13 & 222.58 & 300 & 300 & 281.67 & 242.73 & 208.41 & $1,611.5$ \\
\hline DST & 0 & 0 & 0 & 0 & 0 & +56.13 & +166.45 & +77.42 & 0 & -18.33 & -38.94 & -34.32 & \\
\hline AE & 0.3 & 0 & 0.28 & 12.57 & 38.03 & 45.03 & 39.38 & 37.18 & 39.05 & 20.58 & 0.05 & 0 & 232.45 \\
\hline DET & 33.29 & 38.13 & 52.88 & 39.59 & 12.57 & 0 & 0 & 0 & 0 & 18.33 & 38.94 & 34.32 & 268.02 \\
\hline
\end{tabular}

Table 4: Monthly supplementary irrigation water need for Tomato/Cabbage/Carrot in mm, over Kano State $(1963-1972)$

\begin{tabular}{|c|c|c|c|c|c|c|c|c|c|c|c|c|}
\hline & Jan & Feb & Mar & Apr & May & Jun & Jul & Aug & Sep & Oct & Nov & Dec \\
\hline & & & & & \multicolumn{2}{|c|}{$\begin{array}{l}\text { Crop initial } \\
\text { growth stage }\end{array}$} & \multicolumn{2}{|c|}{$\begin{array}{c}\text { Crop development } \\
\text { stage }\end{array}$} & \multicolumn{2}{|c|}{$\begin{array}{l}\text { Late season } \\
\text { stage }\end{array}$} & & \\
\hline $\mathrm{ET}_{0}(\mathrm{~mm})$ & 33.59 & 38.13 & 53.16 & 52.16 & 50.6 & 45.03 & 39.38 & 37.18 & 39.05 & 38.91 & 38.99 & 34.32 \\
\hline $\mathrm{K}_{\mathrm{c}}$ & & & & & 0.45 & 0.45 & 0.9 & 0.9 & 0.70 & 0.7 & & \\
\hline $\mathrm{ET}_{\text {crop }}$ & & & & & 22.8 & 20.3 & 32.7 & 33.5 & 27.3 & 27.2 & & \\
\hline $\mathrm{P}_{\mathrm{e}}(\mathrm{mm})$ & 0 & 0 & 0 & 0 & 12.8 & 56 & 136.5 & 176.5 & 80.6 & 2.2 & 0 & 0 \\
\hline IR (mm) & & & & & 10.0 & -35.7 & -103.8 & -143.3 & -53.3 & 25 & & \\
\hline
\end{tabular}

For the decade (1973 - 1982) as given in Table 5, total average precipitation was $(623.3 \mathrm{~mm})$ with the highest rainfall recorded in the month of August. Storage also recorded a total average of $(1,547.55$ $\mathrm{mm})$. Soil moisture deficits of up to eight months were recorded in the study area (January to May) 
and (October to December), with a total average of $(282.21 \mathrm{~mm})$ (Table 5). In this decade (19631972), soil moisture recharge was from May to August while the period of soil moisture utilization was from August to October. Water surplus was recorded in the area during the months of August and September at a total average of $(96.47 \mathrm{~mm})$. In the onset of rains which supplementary irrigation required while Intensive irrigation and water conservation practices were required to make up for limited climatic water supply in the dry months (Table 6).

Table 5: The Water Balance over Kano town for the Years (1973- 1982

\begin{tabular}{|c|c|c|c|c|c|c|c|c|c|c|c|c|c|}
\hline & $\mathrm{J}$ & $\mathrm{F}$ & $\mathrm{M}$ & $\mathrm{A}$ & $\mathrm{M}$ & $\mathrm{J}$ & $\mathrm{J}$ & $\mathrm{A}$ & $\mathrm{S}$ & $\mathrm{O}$ & $\mathrm{N}$ & $\mathrm{D}$ & Total \\
\hline P & 0.3 & 0 & 1.29 & 10.19 & 31.54 & 101.09 & 165.7 & 192.46 & 102.92 & 18.11 & 0 & 0 & 623.3 \\
\hline PET & 34.52 & 40.52 & 46.94 & 52.13 & 52.03 & 45.85 & 41.26 & 38.21 & 40.38 & 43.11 & 38.37 & 35.63 & 508.95 \\
\hline ST & 0 & 0 & 0 & 0 & 0 & 55.24 & 179.68 & 300 & 300 & 275 & 236.63 & 201 & $1,547.55$ \\
\hline DST & 0 & 0 & 0 & 0 & 0 & +50.24 & +124.44 & +120.32 & 0 & -25 & -38.37 & 35.63 & \\
\hline AE & 0.3 & 0 & 1.29 & 10.19 & 31.54 & 45.85 & 41.26 & 38.21 & 40.38 & 18.11 & 0 & 0 & 226.83 \\
\hline DET & 3.52 & 40.52 & 45.65 & 41.94 & 20.49 & 0 & 0 & 0 & 0 & 25 & 38.37 & 35.63 & 282.12 \\
\hline
\end{tabular}

Table 6: Monthly supplementary irrigation water need for Tomato/Cabbage/Carrot in mm, over Kano State $(1973-1982)$

\begin{tabular}{|c|c|c|c|c|c|c|c|c|c|c|c|c|}
\hline & Jan & Feb & Mar & Apr & May & Jun & Jul & Aug & Sep & Oct & Nov & Dec \\
\hline & & & & & \multicolumn{2}{|c|}{$\begin{array}{l}\text { Crop initial } \\
\text { growth stage }\end{array}$} & \multicolumn{2}{|c|}{$\begin{array}{l}\text { Crop development } \\
\text { stage }\end{array}$} & \multicolumn{2}{|c|}{ Late season stage } & & \\
\hline $\mathrm{ET}_{0}(\mathrm{~mm})$ & 34.52 & 40.52 & 46.94 & 52.13 & 52.03 & 45.85 & 41.26 & 38.21 & 40.38 & 43.11 & 38.37 & 35.63 \\
\hline $\mathrm{K}_{\mathrm{c}}$ & & & & & 0.45 & 0.45 & 0.9 & 0.9 & 0.70 & 0.7 & & \\
\hline $\mathrm{ET}_{\text {crop }}$ & & & & & 23.4 & 20.6 & 32.7 & 37.1 & 28.3 & 30.2 & & \\
\hline $\mathrm{P}_{\mathrm{e}}(\mathrm{mm})$ & 0 & 0 & 0 & 0 & 8 & 55 & 103 & 127 & 55 & 0 & 0 & 0 \\
\hline IR (mm) & & & & & 15.4 & -34.4 & -70.3 & -89.9 & -26.7 & 30.2 & & \\
\hline
\end{tabular}

In 1983-1992 decade given in Table 7, precipitation had a total average of (609.74 mm). Storage also recorded a total average of $(1,477.6 \mathrm{~mm})$. Soil moisture deficit of up to eight months were also recorded in the study area between (January to May) and (October and December) with a total average of $(285.99 \mathrm{~mm})$ (Table 7). May and August were periods of soil moisture recharge and the period of soil moisture utilization was between August and October. Water surplus was observed in the area in August and September at a total average of $(77.83 \mathrm{~mm})$. Water resources available for groundwater supply, domestic purposes, rainwater harvesting, agricultural purposes and industrial use were therefore scarce as large periods of water deficit were recorded and as water storage, precipitation and surplus were also on the decline as also seen in the supplementary irrigation needs of selected food crops (Table 8).

Table 7: The Water Balance over Kano town for the Years $(1983-1992)$

\begin{tabular}{|c|c|c|c|c|c|c|c|c|c|c|c|c|c|}
\hline & $\mathrm{J}$ & $\mathrm{F}$ & $\mathrm{M}$ & $\mathrm{A}$ & $\mathrm{M}$ & $\mathrm{J}$ & $\mathrm{J}$ & $\mathrm{A}$ & $\mathrm{S}$ & $\mathrm{O}$ & $\mathrm{N}$ & D & Total \\
\hline P & 0 & 0 & 0 & 2.46 & 42.03 & 73.48 & 163.03 & 220.84 & 89.21 & 17.83 & 0.89 & 0 & 609.74 \\
\hline PET & 34.46 & 39.76 & 47.27 & 53.98 & 52.61 & 47.30 & 40.71 & 39.58 & 41.14 & 44.75 & 41.73 & 34.64 & 517.93 \\
\hline ST & 0 & 0 & 0 & 0 & 0 & 26.18 & 148.5 & 300 & 300 & 273.08 & 232.24 & 199.6 & $1,477.6$ \\
\hline DST & 0 & 0 & 0 & 0 & 0 & +26.18 & +122.32 & +151.5 & 0 & -26.92 & -40.84 & -32.64 & \\
\hline AE & 0 & 0 & 0 & 2.46 & 42.03 & 47.30 & 40.71 & 39.58 & 41.14 & 17.83 & 0.89 & 0 & 231.94 \\
\hline DET & 34.46 & 39.76 & 47.27 & 51.52 & 10.58 & 0 & 0 & 0 & 0 & 26.92 & 40.84 & 34.64 & 285.99 \\
\hline
\end{tabular}

Table 8: Monthly supplementary irrigation water need for Tomato/Cabbage/Carrot in mm, over Kano State $(1983-1992)$

\begin{tabular}{|c|c|c|c|c|c|c|c|c|c|c|c|c|}
\hline & Jan & Feb & Mar & Apr & May & Jun & Jul & Aug & Sep & Oct & \multirow[t]{2}{*}{ Nov } & \multirow[t]{2}{*}{ Dec } \\
\hline & & & & & \multicolumn{2}{|c|}{$\begin{array}{l}\text { Crop initial } \\
\text { growth stage }\end{array}$} & \multicolumn{2}{|c|}{$\begin{array}{l}\text { Crop development } \\
\text { stage }\end{array}$} & \multicolumn{2}{|c|}{ Late season stage } & & \\
\hline $\mathrm{ET}_{0}(\mathrm{~mm})$ & 34.46 & 39.76 & 47.27 & 53.98 & 52.61 & 47.30 & 40.71 & 39.58 & 41.14 & 44.75 & 41.73 & 34.64 \\
\hline $\mathrm{K}_{\mathrm{c}}$ & & & & & 0.45 & 0.45 & 0.9 & 0.9 & 0.70 & 0.7 & & \\
\hline $\mathrm{ET}_{\text {crop }}$ & & & & & 23.7 & 21.3 & 36.6 & 35.6 & 28.8 & 31.3 & & \\
\hline $\mathrm{P}_{\mathrm{e}}(\mathrm{mm})$ & 0 & 0 & 0 & 0 & 14 & 32 & 103 & 151 & 47 & 0 & 0 & 0 \\
\hline IR (mm) & & & & & 9.4 & -10.7 & -66.4 & -115.4 & -18.2 & 31.3 & & \\
\hline
\end{tabular}


For the decade (1993 -2002) given in Table 9, the total average of precipitation was $(569.26 \mathrm{~mm})$. Also, the total average of storage had reduced to $(1425.74 \mathrm{~mm})$ in this decade. Furthermore, the study area experienced a period of soil moisture deficit of up to eight months from (January to May) and (October to December) with a total average of $(301.72 \mathrm{~mm}$ ) (Table 9). May to August was recorded as periods of soil moisture recharge. The period of soil moisture utilization was between August and October. Water surplus was recorded in only one month, (September), and it had a total average of $(41 \mathrm{~mm})$ which suggests that there was drought in this decade, as it is a clear drop in the usual amount of months of water surplus recorded in previous decades. From this, it is clear that water resources available for groundwater supply, domestic purposes, rainwater harvesting, agricultural purposes and industrial use were immensely scarce in this decade. In this decade therefore, intensive irrigational and water conservation practices would have been very critical and underground water supply crucially low for the dry season while supplementary irrigation for the onset and rainfall cessation months (Table 10).

Table 9: The Water Balance over Kano town for the Years (1993 - 2002)

\begin{tabular}{|c|c|c|c|c|c|c|c|c|c|c|c|c|c|}
\hline & $\mathrm{J}$ & $\mathrm{F}$ & $\mathrm{M}$ & $\mathrm{A}$ & $\mathrm{M}$ & $\mathrm{J}$ & $\mathrm{J}$ & $\mathrm{A}$ & $\mathrm{S}$ & $\mathrm{O}$ & $\mathrm{N}$ & $\mathrm{D}$ & Total \\
\hline P & 0 & 0.28 & 4.12 & 2.91 & 39.99 & 83.8 & 157.58 & 168.46 & 105.4 & 6.72 & 0 & 0 & 569.26 \\
\hline PET & 35.15 & 40.18 & 47.92 & 55.06 & 53.98 & 48.47 & 42.52 & 40.85 & 42.40 & 46.25 & 42.19 & 35.01 & 529.98 \\
\hline ST & 0 & 0 & 0 & 0 & 0 & 35.33 & 150.39 & 278 & 300 & 260.47 & 218.28 & 183.27 & $1,425.74$ \\
\hline DST & 0 & 0 & 0 & 0 & 0 & +35.33 & +115.06 & +127.61 & +22 & -39.53 & -42.19 & -35.01 & \\
\hline AE & 0 & 0.28 & 4.12 & 2.91 & 39.99 & 48.47 & 42.52 & 40.85 & 42.40 & 6.72 & 0 & 0 & 228.76 \\
\hline DET & 35.15 & 39.9 & 43.8 & 52.15 & 13.99 & 0 & 0 & 0 & 0 & 39.53 & 42.19 & 35.01 & 301.72 \\
\hline
\end{tabular}

Table 10: Monthly supplementary irrigation water need for Tomato/Cabbage/Carrot in $\mathrm{mm}$, over Kano State $(1993-2002)$

\begin{tabular}{|c|c|c|c|c|c|c|c|c|c|c|c|c|}
\hline & Jan & Feb & Mar & Apr & May & Jun & Jul & Aug & Sep & Oct & Nov & Dec \\
\hline & & & & & \multicolumn{2}{|c|}{$\begin{array}{l}\text { Crop initial } \\
\text { growth stage }\end{array}$} & \multicolumn{2}{|c|}{$\begin{array}{l}\text { Crop development } \\
\text { stage }\end{array}$} & \multicolumn{2}{|c|}{ Late season stage } & & \\
\hline $\mathrm{ET}_{0}(\mathrm{~mm})$ & 35.15 & 40.18 & 47.92 & 55.06 & 53.98 & 48.47 & 42.52 & 40.85 & 42.40 & 46.25 & 42.19 & 35.01 \\
\hline $\mathrm{K}_{\mathrm{c}}$ & & & & & 0.45 & 0.45 & 0.9 & 0.9 & 0.70 & 0.7 & & \\
\hline $\mathrm{ET}_{\text {crop }}$ & & & & & 24.3 & 21.8 & 38.3 & 36.8 & 29.7 & 32.4 & & \\
\hline $\mathrm{P}_{\mathrm{e}}(\mathrm{mm})$ & 0 & 0 & 0 & 0 & 14 & 39 & 96.6 & 104.6 & 56.9 & 0 & 0 & 0 \\
\hline IR (mm) & & & & & 10.3 & -17.2 & -58.3 & -67.8 & -27.2 & 32.4 & & \\
\hline
\end{tabular}

For the decade (2003 - 2012), the total average of precipitation surprisingly and unexpectedly had an increase to $(703.88 \mathrm{~mm})$. Also, the total average of storage increased to $(1,618.5 \mathrm{~mm})$ which is another astounding change in the pattern of hydrological behaviour in Kano Town. Also, the study area experienced a period of soil moisture deficit of seven months between (January to April) and (October to December) months which marks yet another change in the usual pattern of the water deficit occurrence from eight months to seven months (Table 11). Soil moisture recharge was recorded between April and July and soil moisture utilization was recorded between July and October, which marks yet another change in the usual pattern of behaviour over the study area in the past decades. Water surplus was recorded in August and September with an astonishing total average of $(151.92 \mathrm{~mm})$. The fact that rainfall amount appreciated during the decade 2003 - 2012 further supports the findings from other authors rainfall conditions improved in the $90 \mathrm{~s}$, followed by a total rainfall recovery in 2000s (Yamusa et al., 2015) . Studies by (Nicholson et al., 2000) and (Ati et al., 2009) have also shown that there was a sign of a recovery and a significant increase in annual rainfalls in the 1990s compared to previous decades. This sign of recovery is also seen in the reducing amounts of water required for supplementary irrigation water needs (Table 12). Water resources available for groundwater supply, domestic purposes, rainwater harvesting, agricultural practices and industrial use are therefore now readily available with soil moisture deficit present at the beginning and end of the year. However, water surplus during the year (August and September) suggests periods of water availability and sufficient surface -run-off in the study area. 
Table 11: The Water Balance over Kano town for the Years $(2002-2012)$

\begin{tabular}{|c|c|c|c|c|c|c|c|c|c|c|c|c|c|}
\hline & $\mathrm{J}$ & $\mathrm{F}$ & $\mathrm{M}$ & $\mathrm{A}$ & $\mathrm{M}$ & $\mathrm{J}$ & $\mathrm{J}$ & $\mathrm{A}$ & $\mathrm{S}$ & $\mathrm{O}$ & $\mathrm{N}$ & $\mathrm{D}$ & Total \\
\hline $\mathrm{P}$ & 0 & 0 & 3.48 & 7.54 & 55.67 & 109.38 & 213.24 & 197.81 & 104.28 & 12.48 & 0 & 0 & 703.88 \\
\hline PET & 35.68 & 40.14 & 49.53 & 55.22 & 54.18 & 48.08 & 42.67 & 41.13 & 42.40 & 41.40 & 41.92 & 37.46 & 529.81 \\
\hline ST & 0 & 0 & 0 & 0 & 1.49 & 62.79 & 233.36 & 300 & 300 & 271.08 & 229.16 & 220.62 & $1,618.5$ \\
\hline DST & 0 & 0 & 0 & 0 & +1.49 & +61.3 & +170.57 & +66.64 & 0 & -28.92 & -41.92 & -8.54 & \\
\hline AE & 0 & 0 & 3.48 & 7.54 & 54.18 & 48.08 & 42.67 & 41.13 & 42.40 & 12.48 & 0 & 0 & 251.96 \\
\hline DET & 35.68 & 40.14 & 46.05 & 47.68 & 0 & 0 & 0 & 0 & 0 & 28.92 & 41.92 & 37.46 & 277.85 \\
\hline
\end{tabular}

Table 12: Monthly supplementary irrigation water need for Tomato/Cabbage/Carrot in $\mathrm{mm}$, over

Kano State $(2003-2012)$

\begin{tabular}{|c|c|c|c|c|c|c|c|c|c|c|c|c|}
\hline & Jan & Feb & Mar & Apr & May & Jun & Jul & Aug & Sep & Oct & Nov & Dec \\
\hline & & & & & \multicolumn{2}{|c|}{$\begin{array}{l}\text { Crop initial } \\
\text { growth stage }\end{array}$} & \multicolumn{2}{|c|}{$\begin{array}{c}\text { Crop development } \\
\text { stage }\end{array}$} & \multicolumn{2}{|c|}{ Late season stage } & & \\
\hline $\mathrm{ET}_{0}(\mathrm{~mm})$ & 35.68 & 40.14 & 49.53 & 55.22 & 54.18 & 48.08 & 42.67 & 41.13 & 42.40 & 41.40 & 41.92 & 37.46 \\
\hline $\mathrm{K}_{\mathrm{c}}$ & & & & & 0.45 & 0.45 & 0.9 & 0.9 & 0.70 & 0.7 & & \\
\hline $\mathrm{ET}_{\text {crop }}$ & & & & & 24.4 & 21.6 & 38.4 & 37.0 & 29.7 & 28.9 & & \\
\hline $\mathrm{P}_{\mathrm{e}}(\mathrm{mm})$ & 0 & 0 & 0 & 0 & 22.7 & 63 & 143 & 127 & 56 & 0 & 0 & 0 \\
\hline IR (mm) & & & & & 1.7 & -41.4 & -104.6 & -90 & -26.3 & 28.3 & & \\
\hline
\end{tabular}

\subsection{Discussion}

This study showed that in the first (5) decades, water deficit occurred over a period of eight (8) months first between (January to May) and (October to December). However, this pattern changed in the last decade (2003-2012) where deficit occurred during (7) months between (January to April) and (October to December). It can therefore be appreciated that the dry season in the study area starts in October and ends in May, which corresponds to the period of dry season of northern Nigeria which equally spans from the month of October to May. However, this pattern has changed over the last decade, suggesting a change in the climatic behaviour over the basin. The periods of soil moisture recharge over the basin occurred between May and August, while soil moisture utilization occurred between August and October. Except in the last decade, where soil moisture recharge occurred between April and July and soil moisture utilization occurred between July and October. From this, it is seen that water was most available in the study area between the months of August and October, (This period coincides with the period of water surplus which occurred between August and September). Therefore, it can be seen activities that are water-dependent would have sufficient water during the months of August to October; but alternative sources of water would be required during the remaining months of the year, as water was scarce during those other months. The steady increase in water deficit and decline in water availability confirms the Sahelian drought that occurred in Nigeria between the 1960's and 1980's and suggests that the drought was at its peak during (the mid 1970's and early 1980's). However, the significant change in the availability of water over the study area due to recent change in climate over the last decade, suggests that water resources will not become totally scarce, but may however become readily available in the future as a result of the changing climate especially for the Kaduna, Sokoto and Rima Rivers in addition to few small streams like the Ka, Zamfara Gurara and Mada Rivers which drain Kano parts of the study area. Therefore, the decadal pattern of the climatic water balance of the study area should be of importance to the government and other hydrological institutions in the state, to guide their activities in the development and planning of water resources of the region.

\subsection{Conclusion}

The major contribution to stream flow to river basins is from rainfall. In this study, it was observed that precipitation, storage, as well as water surplus over the sixty years of study $(1953-2012)$ have been on a steady decline up until the fifth decade (1993 - 2002), where it was at its lowest, this was followed by a sudden and remarkable increase in the next decade $(2003-2012)$. Furthermore, water 
deficit over the sixty years of study, has on the other hand been on a steady increase up until the last decade where it experienced a remarkable drop. The significant change in the availability of water over the study area due to recent change in climate over the last decade, suggests that water resources will not become totally scarce, but may however become readily available in the future as a result of the changing climate especially for the Kaduna, Sokoto and Rima Rivers in addition to few small streams like the Ka, Zamfara Gurara and Mada Rivers which drain Kano parts of the study area. Therefore, the decadal pattern of the climatic water balance of the study area should be of importance to the government and other hydrological institutions in the state, to guide their activities in the development and planning of water resources of the region.

\section{References}

Adefolalu, D. O., (2007). Climate change and economic sustainability in Nigeria. In: Proceedings of the International Conference on Climate Change and Economic Sustainability, Enugu, Nigeria, 12-14 June 2007.

Anyadike, R.N.C., (1987). The Linacre evaporation formula tested and compared to others in various climates over West-Africa. Agricultural and Forest Meteorology, 39, pp. 111-119.

Anyadike, R.N.C., (1992). Water Balance of the Lake Chad Basin. Buttetine des Institute fundamental d'Afrique Novire, 47, pp. 13-28.

Ati, O.F., Stigter, C. J., Iguisi, E.O. and Afolanyan, J.O., (2009). Profile of rainfall change and variability in northern Nigeria 1953-2003. Res. J Environ. Earth Sci, 1, pp. 58-63.

Burt, C. M., (1999). Irrigation Water Balance Fundamentals. In: Proceedings of Conference on Benchmarking Irrigation System Performance Using Water measurement and water balances. San Luis Obispo, C.A., March 10. USCID, Denver, pp. 1-13. ITRC paper 99-101

Dai, A., Lamb, P., Trenberth, K. E., Hulme, M., Jones, P. D. and Xie, P., (2004). The recent Sahel drought is real. Int. J. Climatology, 24, pp. 1323-1331.

Dettinger, M.D. and Diaz, H.F., (2000). Global characteristics of streamflow seasonality and variability. J. Hydromet. 1, pp. 289-310.

Ekpoh, I. J., (1999). Rainfall and Peasant Agriculture in Northern Nigeria. Global Journal of Pure and Applied Sciences, 5, pp. 123-128.

Ekpoh, I. J., (2007). Climate and Society in Northern Nigeria: Rainfall variability and farming. The International Journal Series on Tropical issues, 8, pp. 157-162.

Food and Agriculture Organization of the United Nations FAO (1986). Irrigation Management, Training Manual, No 3. Via delle Terme di Caracalla, 00100 Rome, Italy

Hulme, M., (2001). Climate perspectives on Sahelian desiccation; 1973-1998. Global Environmental Change, 11, pp. 19-29.

Israelsen, O.W. and Hansen, V.E., (1962). Irrigation Principles and Practices, John Wiley and Sons. Inc, New York.

Linacre, E.T., (1977). A simple Formula for estimating evaporation rate in various climate, using temperature data alone. Agriculture and Meteorology, 18, pp. 409-424.

Linacre, E.T., (1992). Climate Data and Resources: A Reference and Guide. London, Routledge.

Mamman, A. B., Oyebanji, J. O. and Peters, S. W., (2002). Nigeria, A People United, A Future Assured. Survey of States, Vol. 2 Millennium Ed., Gabumo House, Calabar 
Nicholson, S.E., Some, B. and Kone, B., (2000). An analysis of recent rainfall conditions in west Africa, including the rainy seasons of the 1997 EI Nino and the $1998 \mathrm{La}$ Nina years. Jouurnal of climate, 13, pp. 2628-2640.

Sauchyn, D. and Kulshreshtha, S., (2008). Climate change impacts on Canada's Prairie Provinces: A summary of our state of knowledge, from "Prairies". In: From Impacts to Adaptation: Canada in a Changing Climate 2007, Edited by D. Lemmen et al., Government of Canada, Ottawa

Tarhule, A. and Woo, M.K., (1998). Changes in rainfall characteristics in northern Nigeria. Int. J. Climatol., 18, pp. 1261-1271.

Thornthwaite, C.W. and Maither, J.R. (1955). The Water Balance, Publications in Climatology VIII, Drexel Institute of Technology, Centerton, NJ, 104P.

Thornthwaite, C.W., (1948). An Approach towards a Rational Classification of Climate. Geographical review, 38, pp. 55 - 94.

Yamusa, M.A., Abubakar, I.U. and Falaki, A. M., (2015). Rainfall variability and crop production in the north western semi-arid zone of Nigeria. Journal of soil science and environmental management, 6(5), pp. 125-131. 